\title{
Clostridial-Induced Type I Polyagglutinability with Associated Intravascular Hemolysis
}

\author{
J. M. Gray, M. L. Beck and H. A. Oberman \\ Department of Pathology, The University of Michigan and St. Joseph Mercy Hospital, \\ Ann Arbor, Mich.
}

The term 'polyagglutinability' refers to abnormal erythrocytes which clump when mixed with any normal adult serum. A well-recognized cause of polyagglutination is activation of the latent $\mathrm{T}$-receptor which is present on all human erythrocytes. Many species of bacteria, as well as viruses of the influenza group, produce neuraminidases capable of activating the normally latent $\mathrm{T}$-receptor in vitro and in vivo. All normal sera, except those from newborn infants, contain anti-T hemagglutinins which react with $\mathrm{T}$-activated erythrocytes.

We recently studied a patient with septicemia whose cells typed as $A B$ but whose serum contained anti-B. She was initially suspected of having acquired a $\mathrm{B}$ antigen, but in vivo $\mathrm{T}$-activation was demonstrated to be the basis for the discrepancy between the forward and reverse grouping. An organism capable of causing T-activation in vitro was cultured from her blood at the time her cells were polyagglutinable; furthermore, it is likely that anti- $T$ in donor plasma caused hemolysis. The classification of polyagglutinability used in this report is that which we recently derived [1].

\section{Case Report}

A 47-year-old white woman was hospitalized on September 17, 1969, with generalized abdominal pain and nausea of 2 days duration. Physical examination revealed abdominal tenderness and a palpable mass in the adnexa. Celiotomy performed on the day of admission revealed loops of ileum bound in the pelvis by fibrous adhesions. There was no significant blood loss, and the signs and symptoms which had been present preoperatively

Accepted: November 2, 1971. 
subsided by the 2nd postoperative day, but on the 6th day the patient developed a wound infection and clinical signs of peritonitis localized to the right lower quadrant.

On the day of admission the patient's blood type was $A$, $R h_{0}$ (D) positive, with no discrepancy between forward and reverse ABO type. During the first 6 days of hospitalization her hemoglobin fell from 15 to $10.2 \mathrm{~g} / 100 \mathrm{ml}$. There was no obvious source of bleeding, and blood was not administered at that time.

On September 24 she was transferred to St. Joseph Mercy Hospital, complaining of abdominal pain. Scleral icterus was present. Her abdomen was distended, and the surgical wound was dehiscent. There were no palpable abdominal masses.

A blood culture grew Clostridium sporogenes. Using several different antisera the patient's red cells were typed as $A B$, but anti-B was present in her serum. Using a broad spectrum reagent, the direct antiglobulin test was weakly positive. However, subsequent tests performed at 25 and $37^{\circ} \mathrm{C}$ in saline, albumin and by the antiglobulin technique failed to elucidate the cause of the direct antiglobulin reaction.

On September 25 a second celiotomy revealed several liters of feculent exudate in the peritoneal cavity. A perforation of the ileum, $60 \mathrm{~cm}$ proximal to the ileocecal valve, was found, and approximately $40 \mathrm{~cm}$ of ileum was resected.

The patient was given 1 unit of blood preoperatively, a 2nd unit during the operation, and 4 more units on September 26. Nevertheless, on September 27, the hemoglobin concentration was only $10.9 \mathrm{~g} / 100 \mathrm{ml}$. Furthermore, on September 26 , after the first 3 units had been given, the serum bilirubin had risen to $8.4 \mathrm{mg} / 100 \mathrm{ml}$. Although the patient's serum did not agglutinate red cells from the six units, her red cells were weakly reactive with the donor's serum in all phases of the minor crossmatches. It should be noted, in this regard, that the antiglobulin serum had not been absorbed with T-activated cells. Free hemoglobin and methemalbumin were detected in her serum.

Continued therapy with antibiotics resulted in gradual clinical improvement. Subsequent transfusions of blood produced the expected elevation of the hemoglobin concentration and no further inconsistency in ABO typing was detected.

\section{Serologic Findings}

The results of tests on washed saline suspensions of red cells are given in table $\mathrm{I}$. The reactivity of the patient's erythrocytes with anti-B serum varied in the specimens obtained on different days. Similarly, reactivity with $A B$ serum and with Arachis hypogoea (anti-T lectin) varied on different days, and the strength of the reactions with anti-B roughly corresponded with those obtained with anti-T.

The anti-A and anti-B typing reagents and serum from a normal group $\mathrm{AB}$ individual were absorbed with $\mathrm{T}$-activated group $\mathrm{O}$ cells. Using these $T$-absorbed antisera, each sample from the patient gave only the reactions expected of type A blood (table II). It was not possible to elute anti-B from the patient's erythrocytes following their incubation with a reactive anti-B serum. However, these eluates contained anti-T, which agglutinated $\mathrm{T}$ activated group $\mathrm{O}$ cells at $4^{\circ} \mathrm{C}$. 
Table I. Pertinent serologic reactions of the patient's red cells

\begin{tabular}{|c|c|c|c|c|c|}
\hline Cell sample & Anti-A & Anti-B & Arachis, anti-T & Group AB serum & saline \\
\hline $9-25-69$ & $+t+t$ & $+t+$ & $+t+t$ & $+t+$ & - \\
\hline $9-26-69$ & $+t+t$ & ++ & ++ & + & - \\
\hline $9-29-69$ & $t+t$ & - & + & + & - \\
\hline $9-30-69$ & $+t+t$ & + & $+t+t$ & + & - \\
\hline $10-1-69$ & $+t+t$ & - & + & - & - \\
\hline $10-28-69$ & $+t+t$ & - & - & - & - \\
\hline $11-19-69$ & $+t+t$ & - & & - & \\
\hline $12-13-69$ & $t+t$ & - & & - & \\
\hline $7-17-70$ & $+t+t$ & - & - & - & - \\
\hline
\end{tabular}

Samples of the patient's serum were tested for their ability to agglutinate $T$-activated group $O$ erythrocytes, and the reactions were compared with the reactivity of the patient's erythrocytes with Arachis anti-T lectin. There was an inverse relationship between the extent of $T$-activation of the red cells and the strength of anti-T in the serum (table III).

The various organisms cultured from the patient's blood, Clostridium sporogenes, $a$-Streptococcus, Enterobacter cloacae, and Citrobacter species, were incubated in broth for $48 \mathrm{~h}$, and cell-free filtrates were tested for their ability to activate the $\mathrm{T}$-receptor of normal group $\mathrm{O}$ red cells. Equal volumes of packed cells and filtrate were incubated for up to $24 \mathrm{~h}$ and then washed.

$T$-activation was indicated by agglutination of the washed cells by anti-T lectin. The only filtrate which proved capable of T-activating erythrocytes in vitro was prepared from the culture of Clostridium sporogenes. Although many pathogenic species of Clostridia produce a lecithinase capable of

Table II. Reactions of patient's red cells with T-absorbed ABO typing reagents (compare with table I)

\begin{tabular}{llll}
\hline Cell samples & Anti-A & Anti-B & Group AB serum \\
\hline $9-25-69$ & ++++ & - & - \\
$9-26-69$ & ++++ & - & - \\
$9-29-69$ & ++++ & - & - \\
$9-30-69$ & ++++ & - & - \\
$10-1-69$ & ++++ & - & - \\
$10-28-69$ & ++++ & - & - \\
\hline
\end{tabular}


Table III. T-activity of red cells correlated with the presence of anti-T agglutinins in the serum

\begin{tabular}{lll}
\hline Sampie & $\begin{array}{l}\text { Reactions of cells with } \\
\text { Arachis, anti-T }\end{array}$ & $\begin{array}{l}\text { Reactions of serum } \\
\text { with T-active cells }\end{array}$ \\
\hline $9-25-69$ & ++++ & + \\
$9-26-69$ & ++ & - \\
$9-29-69$ & + & ++ \\
$9-30-69$ & ++++ & + \\
$10-1-69$ & + & + \\
$10-28-69$ & - & +++ \\
\hline
\end{tabular}

causing hemolysis, Clostridium sporogenes does not usually produce such a lecithinase [6]. Moreover, the organism recovered from this patient did not produce a lecithinase detectable by the Nagler plate method in our laboratory or in the National Communicable Disease Center.

One year after the patient's recovery, further investigations failed to indicate any intrinsic abnormality of the red cells which might have produced hemolysis.

VAN LOGHEM and his colleagues first described intravascular hemolysis due to anti-T in donor blood [4]. Subsequent reports have confirmed that anti-T can produce polyagglutinability as well as hemolysis of red cells $[2,5]$. Rarely polyagglutinability can occur in apparently healthy donors, resulting in possible discrepancies in ABO typing [3].

\section{Summary}

A woman with a clostridial septicemia manifested in vivo type I polyagglutinability of her erythrocytes, presumably due to activation of the latent T-receptor. A filtrate of the Clostridium culture was capable of causing T-activation of erythrocytes in vitro and bacterial products probably caused the T-activation in vivo. Moreover, there was evidence that anti- $\mathrm{T}$ in donor plasma caused lysis of T-active red cells.

\section{Acknowledgements}

We wish to thank Dr. V. R. Dowell of the National Communicable Disease Center for assistance in identifying the species of Clostridium and Dr. E. BRITT, of St. Joseph Mercy Hospital, for preparing cell free bacterial filtrates. 


\section{References}

1 Beck, M. L.; Walker, R. H., and Oberman, H. A.: Atypical polyagglutinability associated with an acquired $B$ antigen. Transfusion (in press).

2 Richard, K. A.; Robinson, R. J., and Worlledge, S. M.: Acute acquired hemolytic anemia associated with polyagglutination. Arch. Dis. Childh. 44: 102 (1969).

3 Stratton, F.: Polyagglutinability of red cells. Vox Sang. 2: 58 (1954).

4 Loghem, J. J. van: Some comments on autoantibody induced red cell destruction. Ann. N.Y. Acad. Sci. 124: 465 (1965).

5 Loghem, J. J. vaN: HART, M. van DeR, and LAND, M. E.; Polyagglutinability of red cells as a cause of severe haemolytic transfusion reaction. Vox Sang. 5: 125 (1955).

6 Wuson, G. S. and MuEs, A. A.: Topley and Wilson's principles of bacteriology and immunity, vol. 1 and 2 (Williams \& Wilkins, Baltimore 1964).

Authors' addresses: J. M. GRAY, M. D., Department of Pathology, St. Joseph Mercy Hospital, Ann Arbor, MI 48104; M. L. BECK, F. I. M. L. T., Research Technologist and H. A. Oberman, M. D., Professor of Pathology and Medical Director, Blood Bank University of Michigan Medical Center, 1335 East Catherine St., Ann Arbor, MI 48104 (USA) 